\title{
Jurist-Diction
}

Volume 1 No. 1, September 2018

Article history: Submitted 2 August 2018; Accepted 15 August 2018; Available online 3 September 2018

\section{PENGALIHAN HAK ATAS MEREK TERDAFTAR DENGAN CARA WAKAF}

Bagas Saka Dhiwangga

bagas.saka.dhiwangga-2014@fh.unair.ac.id Universitas Airlangga

\begin{abstract}
Trademark is one of the element of intellectual property rights, the manifest of intellectual works that give distinguish element for goods or services by the subject of rights which indicate the identify, characteristics, and the origin of goods and services that it has made. Trademark are regulated in act number 20 of 2016 that called trademark and geographical indications. Article 41 point 1 of this act explain that trademark can be transferred using waqf method. But, this article only explains that the terms and procedures of transferring trademark with waqf method are regulated in Ministerial Regulations. However, until now the regulations referred to in those articles have not yet been established. Faced this situation, the presence of Waqf Law is very necessary in order to fill the regulatory vacuum on the terms and procedures of trademark endowments.
\end{abstract}

Keywords: Trademark; Waqf; Endowments Rights.

\begin{abstract}
Abstrak
Merek adalah salah satu bagian dari elemen Hak Kekayaan Intelektual yang merupakan bentuk perwujudan dari karya intelektual yang berfungsi sebagai unsur pembeda atas barang atau jasa yang diproduksi oleh subjek hak yang menunjukan identitas, ciri, dan asal-usul barang atau jasa yang telah dibuatnya. Merek diatur diatur dalam Undang-Undang No.20 Tahun 2016 tentang Merek dan Indikasi Geografis. Pasal 41 angka 1 undang-undang tersebut menjelaskan bahwa merek dapat dialihkan salah satunya dengan metode wakaf. Namun, pasal tersebut hanya menjelaskan bahwa syarat dan tata cara pengalihan merek dengan wakaf diatur dalam Peraturan Menteri. Sampai saat ini peraturan yang dimaksud dalam pasal tersebut belum juga dibentuk. Menghadapi situasi seperti ini, kehadiran Undang-Undang Wakaf sangat diperlukan dalam rangka mengisi kekosongan pengaturan tentang syarat dan tata cara wakaf merek.
\end{abstract}

Kata Kunci: Merek; Pengalihan Hak; Wakaf.

\section{Pendahuluan}

Intellectual property merupakan istilah yang tercipta pada abad ke-19. ${ }^{1}$ Pakar hukum kekayaan intelektual mencoba menggambarkan makna intellectual property dengan mengacu pada subjek yang menjadi bagian rezim hukum kekayaan intelektual, seperti paten, hak cipta, dan merek daripada menjelaskan konsep intellectual property secara koheren. Menurut Michael Spence, para pakar hukum tersebut lebih tertartik untuk menjelaskan konsep kekayaan intelektual dengan

\footnotetext{
1 Micahael Spence, Intellectual Property, Oxford University Press, London, 2007[1].
} 
mengkaji subjek elemenya, seperti hak cipta, paten, dan merek. Sementara hal yang berkaitan dengan konsep intellectual itu sendiri ditinggalkan. ${ }^{2}$

Berbeda dengan Michael Spence, Robert M. Sherwood berpendapat bahwa Intellectual property merupakan frasa yang tidak dapat dipisahkan satu sama lain, yakni terdiri atas kata intellectual dan property. Dengan kata lain frasa tersebut menggabungkan dua unsur. Pertama, intellectual adalah hasil suatu ide, invensi, atau ekspresi kreatif. Kedua, frasa itu juga bermakna sebagai suatu willingness untuk memberikan status hukum sebagai kekayaan bagi penemuan. ${ }^{3}$ Dalam penjelasan lainya, istilah intellectual pada kekayaan intelektual sebenarnya tidak semata-mata berkaitan dengan sesuatu yang tidak berwujud (intangibility). Istilah kekayaan intelektual lebih mengindikasikan bahwa kekayaan jenis ini dihasilkan oleh aktivitas mental manusia. Objek dari kekayaan intelektual merupakan hak kebendaan yaitu hak atas benda yang bersumber dari hasil kerja otak, rasio, atau penalaran, sehingga dianggap sebagai sesuatu yang tidak berwujud atau immaterial. ${ }^{4}$

Sehingga dapat disimpulkan bahwa definisi intellectual property rights adalah hak yang dimiliki perorangan atau badan hukum untuk memperoleh perlindungan hukum atas kekayaan intelektualnya sesuai dengan peraturan perundang-undangan. Selanjutnya, istilah intellectual property right atau Hak Kekayaan Intelektual dalam tulisan ini disebut HKI.

Dalam HKI, terdapat beberapa subjek elemen hak, salah satunya adalah hak atas merek yang selanjutnya dalam tulisan ini disebut merek. Merek termasuk dalam subjek elemen HKI. Hal ini beranjak dari pemikiran Abdulkadir Muhammad yang menjelaskan tentang konsep HKI. Menurutnya, jika ditelusuri lebih mendalam konsep HKI meliputi: ${ }^{5}$

a. Hak milik hasil pemikiran (intelektual), melekat pada pemiliknya, bersifat

\footnotetext{
2 Ibid.

3 Budi Agus Riswandi, Wakaf Hak Kekayaan intelektual, Pusat HKI FH UII, Yogyakarta.[5].

4 Mas Rahmah, Sekuritas Hak Kekayaan Intelektual Untuk Penerbitan Sukuk, Disertasi, Program Doktor Ilmu Hukum, Fakultas Hukum Universitas Airlangga, 2012.[127].

5 Abdulkadir Muhammad, Kajian Hukum Ekonomi Hak Kekayaan Intelektual, Citra Aditya Bhakti, Bandung, 2001.[1].
} 
tetap dan eksklusif;

b. Hak yang diperoleh pihak lain atas ijin dari pemilik dan bersifat sementara.

Menurut sistem hukum Anglo Saxon, HKI diklasifikasikan menjadi Hak Cipta (Copyright) dan Hak Milik Perindustrian (Industrial Property Rights). Adapun pembagian kategori HKI tersebut adalah sebagai berikut: ${ }^{6}$

a. Hak Cipta (Copyright);

b. Hak Kaitan (Neighbouring Rights).

Sedangkan Hak Milik Perindustrian (Industrial Property Rights) menurut Convention Establishing the World Intellectual Property Organization (WIPO) diklasifikasikan sebagai berikut:

a. Paten (Patent);

b. Model dan Rancang Bangun (Utility Models);

c. Desain Industri (Industrial Design);

d. Merek Dagang (Trade Mark);

e. Nama Dagang (Trade Name); dan

f. Sumber Tanah dan Sumber Asal (Indication of Source or Appelation of Origin).

Kemudian ditambahkan beberapa elemen lainya yaitu Rahasia Dagang (Trade Secret), Merek Jasa (Service Mark), dan Perlindungan dan Persaingan Curang (Unfair Competition Protection). TRIPS's (Trade Related Aspects of Intellectual Property Right) menambahkan dua bidang lagi ke dalam kelompok hak-hak diatas, yaitu:

a. Perlindungan Varietas Tanaman (Varieties of Plants Protection);

b. Desain Tata Letak Sirkuit Terpadu (Layout Design of Integrated Circuit).

Jadi, beranjak dari pemahaman tentang konsep HKI diatas, merek dapat dikategorikan dalam subjek elemen HKI.

Pada dasarnya sifat-sifat hak yang dimiliki oleh pemegang hak merek adalah sama dengan sifat-sifat yang melekat pada HKI, yaitu bersifat eksklusif, individual, dan mutlak. Sifat eksklusif, individual, dan mutlak dalam HKI berarti bahwa hasil ciptaan yang berasal dari kreatifitas dan hasil olah pikir kemampuan intelektual seseorang atau kelompok dapat dipertahankan kedudukanya apabila ada pihak lain yang dengan sengaja melakukan peniruan terhadap hasil karyanya. Pemilik hak

${ }^{6} \quad$ Ibid. [4]. 
dapat menuntut terhadap pelanggaran yang dilakukan oleh siapapun dan pemegang HKI yang sah tersebut mempunyai hak monopoli, yaitu pemilik atau pemegang hak dapat mempergunakan haknya untuk melarang siapapun yang akan memproduksi barang atau jasa miliknya, kecuali jika telah memperoleh persetujuan darinya.

Mengingat bahwa hak merek merupakan hak yang bersifat khusus, maka hak itu dapat dipertahankan terhadap siapapun juga. Jika ada orang lain yang beritikad tidak baik melaksanakan hak tersebut tanpa seizin pemegang hak atas merek, maka telah terjadi pelanggaran atas hak yang bersifat khusus tadi. ${ }^{7}$

Dalam UU Merek Pasal 41 angka (1), disebutkan bahwa merek terdaftar beralih atau dialihkan karena pewarisan, wasiat, wakaf, hibah, perjanjian, dan sebab lain yang dibenarkan oleh peraturan perundang-undangan. Sebaliknya, hal berbeda kita temukan ketika melihat metode pengalihan merek berdasarkan undang-undang sebelumnya, yaitu Undang-Undang No.15 Tahun 2001 tentang Merek. Dalam Pasal 40 Undang-Undang No.15 Tahun 2001, disebutkan bahwa pengalihan merek hanya terbatas pada cara pewarisan, wasiat, hibah, perjanjian, dan atau sebab lain yang dibenarkan oleh peraturan perundang-undangan. Dalam metode pengalihanya tidak terdapat kata "wakaf". Namun setelah itu, wakaf dimunculkan dalam metode pengalihan merek pada UU Merek terbaru. Merupakan pembahasan yang menarik sebenarnya dengan melihat apa yang terjadi terhadap UU Merek terbaru yang memasukan unsur wakaf dalam metode pengalihan merek.

Penyebutan wakaf sebagai metode pengalihan merek akan menjadi perbincangan yang menarik. Karena pada dasarnya sifat antara merek dan wakaf saling bertolak belakang. Wakaf memiliki dasar filosofi yang berbeda dengan merek. Wakaf memiliki filosofi kepemilikan bersama atau komunal. Sedangkan merek memiliki filosofi kepemilikan yang eksklusif dan individual. ${ }^{8}$

Masalah utama wakaf merek saat ini adalah tidak diaturnya tentang tata cara pelaksanaan wakaf merek dalam UU Merek. Pasal 41 UU Merek hanya menjelaskan

7 Agung Sujatmiko, Perjanjian Lisensi Merek Terkenal, Mimbar Hukum Fakultas Hukum UGM, Vol. 22, 2010.[1].

8 Budi Agus Riswandi, Op.Cit.[135]. 
bahwa syarat dan tata cara pengalihan merek dengan wakaf diatur dalam Peraturan Menteri. Namun, sampai saat ini peraturan yang dimaksud dalam pasal tersebut belum juga dibentuk. Sehingga di sini terjadi kekosongan hukum (rechtsvacuum). Menghadapi situasi seperti ini, kehadiran UU Wakaf sangat diperlukan dalam rangka mengisi kekosongan pengaturan tentang syarat dan tata cara wakaf merek.

\section{Pengertian dan Syarat Wakaf}

Dalam Pasal 1 angka 1 Undang-Undang No. 41 Tahun 2004 tentang Wakaf, wakaf diartikan sebagai perbuatan hukum wakif untuk memisahkan dan/atau menyerahkan sebagian harta benda miliknya untuk dimanfaatkan selamanya atau untuk jangka waktu tertentu sesuai dengan kepentinganya guna keperluan ibadah dan/atau kesejahteraan umum menurut syariah.

Di Indonesia sekarang ini, wakaf di kenal dan dilaksanakan dengan tujuan utama, yaitu dipergunakan untuk peningkatan kesejahteraan bagi masyarakat Indonesia. Wakaf juga dapat dijadikan solusi untuk memperkecil kesenjangan antara "si kaya" dan "si miskin". Doktrin dalam ajaran islam mewajibkan bagi si kaya untuk mendistribusikan sebagian hartanya kepada sesama agar harta tersebut tidak hanya berputar di lingakaran orang-orang kaya saja. ${ }^{9}$

Wakaf merupakan suatu perbuatan hukum, oleh sebab itu dalam pelaksanaanya harus memperhatikan tentang syarat-syarat dan pengaturan tentang tata cara wakaf. Jumhur ulama menyatakan bahwa syarat dan rukun wakaf ada 4 (empat), yaitu: ${ }^{10}$

1. Waqif (Orang yang mewakafkan hartanya);

2. Mauquf (Harta yang diwakafkan);

3. Mauquf 'alaih (Tujuan wakaf/orang yang diserahi untuk mengelola harta wakaf); dan

4. Sighat (Pernyataan waqif untuk mewakafkan hartanya).

Dalam UU Wakaf, menyatakan bahwa unsur wakaf ada 6 (enam), yakni wakif, nadzir, harta benda wakaf, ikrar wakaf, peruntukan harta benda wakaf, dan jangka waktu wakaf. Namun secara garis besar bermakna sama.

\footnotetext{
9 Ibid.[127].

${ }^{10}$ Faishal Haq, Hukum Perwakafan Di Indonesia, Rajawali Pers, Jakarta, 2017.[6].
} 
Praktik wakaf yang dikenal dalam ajaran syariat Islam, bila dilihat dari segi ditunjukkan kepada siapa wakaf itu, maka wakaf dapat dibagi menjadi 2 (dua) macam. Pertama, wakaf itu ada kalanya untuk anak cucu atau kaum kerabat dan kemudian sesudah mereka itu untuk orang-orang fakir miskin. Wakaf yang demikian itu dinamakan wakaf ahli atau wakaf $d z u r r i$ (keluarga). Kedua, terkadang pula wakaf itu diperuntukkan bagi kebajikan semata-mata. Wakaf yang demikian dinamakan wakaf khairi (kebajikan). ${ }^{11}$

\section{Dasar Hukum Wakaf}

Terdapat beberapa sumber hukum yang menjadi pedoman dalam melaksanakan praktik wakaf di Indonesia. Namun, pada umumnya dibagi menjadi sumber hukum islam dan sumber hukum positif (peraturan perundang-undangan).

Sumber hukum islam bisa dikatakan sumber hukum materil bagi pelaksaan wakaf. Karena, hal ini merupakan akibat dari konsekuensi wakaf yang merupakan kegiatan yang disyariatkan oleh agama tertentu yakni islam, maka tata cara dan pedoman pelaksanaanya harus berdasarkan syariat islam. Sementara itu, kedudukan hukum positif di sini adalah sebagai payung hukum dari legalitas praktik wakaf di Indonesia.

Adapun Sumber hukum islam yang menjadi dasar dalam pelaksanaan praktik wakaf antara lain Al-Quran, Al-Hadist dan $A r-R o ' y u$ (akal). ${ }^{12}$ Dalam kitabnya, Al-Quran tidak menjelaskan secara eksplisit tentang wakaf, namun hal itu bukan berarti tidak ada satu ayat-pun dalam Al-Quran yang menjelaskan tentang wakaf.

Surat Al-Imran Ayat 92:

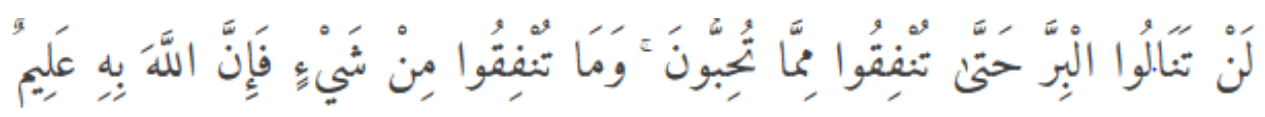

Artinya:

"Kamu sekali-kali tidak sampai kepada kebajikan (yang sempurna), sebelum kamu menafkahkan sebagian harta yang kamu cintai. Dan apa saja yang kamu nafkahkan maka sesungguhnya Allah mengetahuinya."

11 Kementrian Agama Republik Indonesia, Wakaf Fiqh, www.kemenag.go.id, Juli 2006, h.15, dikunjungi pada tanggal 1 April 2018.

12 Ibid.[11]. 
Surat Al-Baqarah Ayat 261:

Artinya:

"Perumpamaan (nafkah yang dikeluarkan oleh) orang-orang yang menafkahkan hartanya di jalan Allah adalah serupa dengan sebutir benih yang menumbuhkan tujuh bulir, pada tiap-tiap bulir seratus biji. Allah melipat gandakan (ganjaran) bagi siapa yang Dia kehendaki. Dan Allah Maha Luas (karunia-Nya) lagi Maha Mengetahui."

Uraian di atas adalah contoh beberapa ayat dalam surat-surat Al-Quran yang memberikan pandangan tentang keisitimewaan wakaf.

Sumber hukum wakaf yang selanjutnya adalah berasal dari hukum positif (peraturan perundang-undangan). Di Indonesia sampai saat ini, peraturan perundang-undangan yang mengatur secara khusus mengenai wakaf adalah:

1. Undang-Undang Nomor 41 Tahun 2004 tentang Wakaf (Lembaran Negara Republik Indonesia Tahun 2004 Nomor159);

2. Peraturan Pemerintah Nomor 42 Tahun 2006 tentang Pelaksanaan Undang Undang Nomor 41 Tahun 2004 tentang Wakaf (Lembaran Negara Republik Indonesia Tahun 2006 Nomor 105);

3. Peraturan Badan Wakaf Indonesia Nomor 1 Tahun 2008 tentang Prosedur Penyusunan Rekomendasi terhadap Permohonan Penukaran/ Perubahan Status Harta Benda Wakaf; dan lain-lain.

\section{Pengertian Merek}

Pasal 1 angka 1 UU Merek, menjelaskan tentang definisi merek yaitu tanda yang dapat ditampilkan secara grafis berupa gambar, logo, nama, kata, huruf, angka, susunan warna, dalam bentuk 2 (dua) dimensi dan/atau 3 (tiga) dimensi, suara, hologram, atau kombinasi dari 2 (dua) atau lebih unsur tersebut untuk membedakan barang dan/atau jasa yang diproduksi oleh orang atau badan hukum dalam kegiatan perdagangan barang dan/atau jasa.

Definisi lain menyebutkan merek adalah salah satu bagian dari HKI yang merupakan bentuk perwujudan dari karya intelektual yang berfungsi sebagai unsur pembeda atas barang atau jasa yang diproduksi oleh subjek hak yang menunjukan 
identitas, ciri, dan asal-usul barang atau jasa yang telah dibuatnya. Dalam definisi lain, merek merupakan tanda suatu produk yang mengidentifikasi produk suatu perusahaan dan membedakan (capable of distinguishing) dari produk barang/jasa sejenis dengan perusahaan lain atau memiliki daya penentu (individualisering). ${ }^{13}$

\section{Dasar Hukum Merek}

1. Undang-Undang Nomor 19 Tahun 1992 tentang Merek (Lembaran Negara RI Tahun 1992 Nomor 81);

2. Undang-Undang Nomor 14 Tahun 1997 tentang Perubahan UU Nomor 19 Tahun 1992 tentang Merek (Lembaran Negara RI Tahun 1997 Nomor 31);

3. Undang-Undang Nomor 15 Tahun 2001 tentang Merek (Lembaran Negara RI Tahun 2001 Nomor 110); dan

4. Undang-Undang Nomor 20 Tahun 2016 tentang Merek dan Indokasi Geografis (Lembaran Negara RI Tahun 2016 Nomor 252);

\section{Merek sebagai Hak Kebendaan}

Berbicara tentang eksistensi merek, maka tidak akan bisa lepas dari bingkai HKI. Karena merek merupakan salah satu bagian dari HKI itu sendiri. Merek merupakan suatu hak yang dilindungi oleh hukum dalam pelaksanaanya. Selain itu, merek termasuk dalam kategori benda tidak berwujud dalam perluasan makna dalam hukum kekayaan. Hukum kekayaan mengatur tentang hubungan hukum yang berkaitan dengan sesuatu yang bernilai ekonomis. Dalam konteks pembicaraan sistem hukum di negara yang menganut Civil Law, bidang hukum kekayaan ini mencakup hukum benda (zakenrecht) dan hukum perikatan (verbintenissenrecht).

Makna dari hukum kekayaan ini sama artinya dengan makna law of property yang dikenal dalam sistem Common Law. Dalam Black's Law Dictionary dikatakan bahwa law of property merupakan kategori hukum yang berkaitan dengan hak seseorang terhadap benda yang penuntutanya dapat dipertahankan kepada setiap orang. ${ }^{14} \mathrm{Jadi}$, dapat dikatakan bahwa merek yang

${ }^{13}$ Rahmi Jened, Implikasi Persetujuan TRIPs Bagi Perlindungan Merek, Yuridika Fakultas Hukum Universitas Airlangga, Surabaya, 2000.[1].

${ }^{14}$ Budi Agus Riswandi, Op.Cit..[2]. 
merupakan bagian dari HKI adalah bagian dari makna benda yang dimaksud dalam hukum kekayaan.

Di Indonesia yang menganut sistem hukum Civil Law, pengaturan tentang hukum kekayaan diatur dalam Burgerlijk Wetboek (BW) atau biasa disebut KUHPerdata. Yakni semua hal yang berkaitan dengan hukum benda diatur dalam Buku II BW, sedangkan hal-hal yang berkaitan dengan hukum perikatan diatur dalam Buku III BW.

Pasal 499 BW menjelaskan bahwa kebendaan adalah setiap barang dan hak yang dapat dikuasai dengan hak milik. Dari definisi tersebut, dapat ditarik kesimpulan bahwa yang dimaksud dengan benda adalah segala sesuatu yang dapat dijadikan hak milik. Dengan pemaknaan tersebut, berakibat pemaknaan benda sangat abstrak. Makna benda dapat kita maknai sebagai barang dan hak berdasar ketentuan BW. Barang merupakan benda berwujud dan hak merupakan benda tidak berwujud. Pemaknaan benda di dalam BW sering kali tidak membedakan antara mana yang disebut barang atau hak. Hal ini dapat dibuktikan dari tidak adanya pengaturan dalam BW yang mengatur tentang kedua hal tersebut.

Merek dalam hukum kekayaan dimaknai sebagai benda yang berupa hak. Merek dikatakan benda karena memenuhi unsur-unsur benda yang dimaksud oleh Pasal 499 BW. Menurut pasal tersebut, benda adalah sesuatu yang dapat dikuasai dengan hak milik, dan merek memenuhi unsur pasal tersebut, karena merek dapat dikuasai dengan hak milik, yakni dapat dibuktikan dengan sertifikat kepemilikan lazimnya. Sedangkan, merek dikatakan sebagai hak, karena wujudnya yang abstrak namun dapat dikuasai dengan hak milik.

Jika kita berbicara tentang hukum benda maka sangat erat hubunganya dengan hak kebendaan. Makna dari hak kebendaan (zakelijkrecht) adalah hak mutlak atas suatu benda di mana hak tersebut memberikan kekuasaan langsung atas suatu benda dan dapat dipertahankan terhadap siapapun juga. ${ }^{15}$ Sehingga dari uraian diatas dapat dikatakan bahwa dalam merek melekat hak kebendaan, karena

15 Sri Soedewi Masjchoen Sofwan, Hukum Perdata:Hukum Benda, Liberty, Yogyakarta, 1981.[24]. 
merek termasuk dalam kategori benda yang dimaksud dalam hukum kekayaan. Merek dalam hukum kekayaan dikategorikan dalam benda yang tidak berwujud, karena bentuknya yang berupa hak. Oleh karena merek disebut sebagai benda, maka akibatnya merek bisa dialihkan hak miliknya. Sesuai dengan judul tulisan ini maka merek dapat dialihkan, yakni salah satu caranya dengan cara wakaf, karena melekat hak kebendaan di dalamnya.

\section{Merek sebagai Objek Harta Benda Wakaf}

Pengaturan tentang merek sebagai objek wakaf sebenarnya dapat dilihat dari regulasi yang berkaitan dengan wakaf dan merek itu sendiri. Inventarisasi dari regulasi tersebut terlihat baik pada peraturan perundang-undangan secara vertikal maupun secara horizontal. Secara vertikal contohnya adalah pengaturan dalam Konstitusi. Secara horizontal contohnya adalah UU Wakaf dan UU Merek.

Secara horizontal berdasarkan kacamata UU Wakaf. Merek termasuk dalam objek harta benda wakaf. Menurut Pasal 16 huruf b UU Wakaf, benda bergerak yang termasuk dalam objek harta benda wakaf adalah:

a) Uang;

b) Logam mulia;

c) Surat berharga;

d) Kendaraan;

e) Hak Atas Kekayaan Intelektual;

f) Hak sewa; dan

g) Benda bergerak lain sesuai dengan ketentuan syariah dan peraturan perundangundangan yang berlaku.

Dijelaskan lebih lanjut lagi mengenai merek sebagai objek harta benda wakaf di dalam Pasal 21 huruf b PP Wakaf. Hak Atas Kekayaan Intelektual yang dimaksud diatas berupa:
a) Hak cipta;
b) Hak merek;
c) Hak paten;
d) Hak desain industri;
e) Hak rahasia dagang;
f) Hak sirkuit terpadu;
g) Hak perlindungan varietas tanaman; dan/atau
h) Hal lainya. 
Berdasarkan uraian diatas, maka dapat dikatakan merek merupakan salah satu objek harta benda wakaf yang dimaksud dalam UU Wakaf.

Berdasarkan kacamata UU Merek, merek menjadi salah satu objek wakaf dengan merujuk pada ketentuan Pasal 41 ayat (1) huruf c UU Merek, menyebutkan bahwa hak atas merek terdaftar dapat beralih atau dialihkan karena wakaf. Jangkauan yang lebih luas jika dibandingkan dengan pengaturan merek yang sebelumnya. Objek harta benda wakaf belum dikenal dalam undang-undang terdahulunya yaitu UndangUndang No.15 Tahun 2001 tentang Merek. Di dalam undang-undang tersebut, metode pengalihan dengan cara wakaf atas merek belum diatur, sehingga dapat dikatakan titik balik dari perkembangan wakaf merek di Indonesia ditandai dengan dimasukannya metode wakaf dalam pengalihan merek berdasar UU Merek terbaru.

\section{Syarat Materil Wakaf Merek}

UU Wakaf mengkategorikan harta benda wakaf menjadi dua jenis, yaitu benda bergerak dan benda tidak bergerak. Hal tersebut tentunya memberikan konsekuensi bahwa masing-masing dari jenis benda tersebut memiliki perbedaan dalam hal syarat-syarat dan tata cara pelaksanaanya. Untuk memahami lebih lanjut mengenai mekanisme pengalihan dari jenis-jenis benda tersebut maka secara umum penulis membaginya menjadi tiga kategori, yaitu wakaf benda tidak bergerak berwujud berupa tanah, wakaf benda bergerak berwujud berupa uang tunai, dan wakaf benda bergerak tidak berwujud berupa merek. Hal ini tentunya untuk memudahkan pemahaman tentang perbandingan mekanisme pengalihan wakaf merek dengan wakaf harta benda lainya.

Dalam hal pengalihan merek, UU Wakaf dan PP Wakaf tidak mengatur secara khusus mengenai tata caranya, namun hanya mengatur secara umum melalui pendekatan pengalihan HKI sebagai objek wakaf. Begitu juga dalam UU Merek terbaru masih belum mengatur tentang tata cara pengalihan merek dengan cara wakaf secara khusus. Melihat kondisi yang demikian, maka di sini akan dibahas mengenai tata cara pengalihan merek melalui pendekatanpendekatan HKI. 
Merek yang dapat diwakafkan adalah merek yang sesuai dengan ketentuan syariah. Hal ini tidak lepas dari kedudukan merek dalam wakaf merek yakni yang hanya sebagai objek wakaf. Sedangkan subjek kegiatan utamanya adalah wakaf. Merujuk pada definisi wakaf yang mengatakan wakaf dilaksanakan guna keperluan ibadah dan/atau kesejahteraan umum berdasar syariah, wakaf merupakan kegiatan yang disyariatkan oleh agama islam, jadi idealnya semua hal yang berkaitan dengan syarat-syarat formil dan materil kegiatan wakaf harus sesuai dengan syariah, karena memang wakaf merupakan kegiatan yang dianjurkan oleh agama islam. Oleh karena syarat-syarat formil dan materil harus sesuai dengan syariah, maka konsekuensinya kedudukan objek wakaf di sini juga harus sesuai dengan syariah.

Argumen ini diperkuat dengan kita melihat ketentuan macam objek harta benda wakaf berupa benda bergerak yang diatur dalam Pasal 16 ayat (3) huruf g UU Wakaf yang mengatakan: (Wakaf dapat dilakukan terhadap) "Benda bergerak lain sesuai dengan ketentuan syariah dan peraturan perundang-undangan yang berlaku."Secara eksplisit, pasal tersebut menjelaskan bahwa objek harta benda wakaf harus sesuai dengan ketentuan syariah dan peraturan perundang-undangan. Berdasarkan hal tersebut maka sudah barang tentu benda-benda yang dapat dijadikan sebagai objek wakaf haruslah sesuai dengan syariah, dan hal ini berlaku bagi seluruh objek wakaf termasuk merek.

Berdasarkan uraian di atas, maka merek yang dapat menjadi objek wakaf haruslah merek yang sesuai dengan syariah (sesuai dengan Al-Qur'an, hadist, dan fikih). Sementara untuk merek-merek yang tidak sesuai dengan syariah tidak bisa menjadi objek wakaf. Merek yang tidak sesuai dengan syariah contohnya adalah merek minuman keras, merek makanan non-halal (misalnya produk makanan babi), karena memang produk-produk tersebut dilarang dalam ajaran islam untuk dikonsumsi.

Dalam hal pengambilan manfaat, pelaksanaan wakaf merek berbeda dengan objek wakaf lainya, misalnya jika dibandingkan dengan wakaf tanah. Wakaf tanah yang diperuntukan pembangunan masjid sebagai tempat ibadah, tidak ada unsur komersialisasi didalamnya, karena memang tujuanya hanya untuk dijadikan sebagai tempat ibadah. Namun berbeda halnya dengan wakafmerek, dalam hal pemanfaatanya, 
wakaf merek sangat bergantung pada sektor komersialisasi. Karena keberadaan merek dalam dunia usaha tidak bisa dilepaskan dari kegiatan jual beli produk barang/jasa. Sehingga unsur komersialisasi melekat erat dalam kaitanya pengambilan manfaat dari wakaf merek. Jadi komersialisasi wakaf merek dibolehkan selama hal tersebut memberikan keuntungan dan manfaat bagi tujuan peruntukan wakaf merek, tentunya komerisialisasi tersebut masih berada di dalam bingkai syariah.

\section{Prosedur Formil Wakaf Merek}

Wakaf merek, seperti halnya wakaf lainya dilakukan dengan alat bukti autentik, yaitu sertifikat kepemilkan merek yang dibuat oleh pihak berwenang yakni Direktorat jendral HKI dan telah dimuat dalam Daftar Umum HKI. Berikut akan dijabarkan mengenai tata cara wakaf merek dengan menggunakan pendekatan wakaf HKI.

Dalam hal tata cara pengalihan benda bergerak tidak berwujud, PP Wakaf mengaturnya. Hal pertama yang harus dilakukan wakif untuk mewakafkan merek yang dimilikinya adalah dengan mengajukan permohonan pengalihan HKI kepada Direktorat Jendral HKI harus menyertakan AIW yang diterbitkan oleh PPAIW. PPAIW dalam hal objek wakaf merek adalah Kepala KUA dan/atau pejabat lain yang ditunjuk oleh menteri, berdasarkan Pasal 37 ayat (2) PP Wakaf. Dalam proses pembuatan AIW, dijelaskan dalam Pasal 34 PP Wakaf, yaitu:

Tata cara pembuatan AIW benda tidak bergerak selain uang dilaksanakan sebagai berikut:

a. Sesuai dengan peraturan perundang-undangan;

b. PPAIW meneliti kelengkapan persyaratan administrasi perwakafan dan keadaan fisik benda wakaf;

c. Dalam hal ketentuan sebagaimana dimaksud pada huruf $b$ terpenuhi, maka pelaksaaan ikrar wakaf dan pembuatan AIW dianggap sah apabila dilakukan dalam Majelis Ikrar Wakaf. Di dalam Majelis Ikrar Wakaf, pernyataan kehendak wakif dituangkan dalam bentuk AIW sesuai dengan jenis harta benda yang diwakafkan, diselenggarakan dalam Mejelis Ikrar Wakaf yang dihadiri oleh nadzir, mauqu alaih, dan sekurang-kurangnya 2 (dua) orang saksi;

d. AIW yang telah ditandatanganni oleh wakif, nadzir, 2 (dua) orang saksi, dan/ atau mauquf alaih disahkan oleh PPAIW; dan

e. Salinan AIW disampaikan kepada:

1. Wakif; 
2. Nadzir;

3. Mauquf Alaih; dan

4. Direktorat Jendral HKI dalam hal objek wakaf adalah merek.

Setelah AIW terbentuk, maka langkah selanjutnya adalah melakukan pendaftaran. Wakif menyerahkan tanda bukti kepemilikan merek berupa sertifikat kepemilikan kepada PPAIW dengan disertai surat keterangan pendaftaran dari Ditjen HKI. Untuk kemudian PPAIW mendaftarkan AIW tersebut ke instansi yang berwenang, dalam hal ini adalah Ditjen HKI. Pengalihan merek wajib dimohonkan pencatatanya kepada Ditjen HKI untuk dicatat dalam Daftar Umum HKI Merek, dengan disertai dokumen-dokumen pendukung. Pengalihan merek terdaftar yang telah dicatat, dimumkan dalam Berita Resmi HKI Merek. Pencatatan pada Daftar Umum akan memberikan akibat hukum pada pihak ketiga. Dengan dicatatnya pengalihan merek dengan cara wakaf pada Daftar Umum maka secara otomatis sejak saat itu, penerima manfaat dari merek tersebut beralih dari wakif kepada nadzir sebagai pengelola harta benda wakaf. Dan semua manfaat yang diperoleh dari merek tersebut sepenuhnya digunakan untuk kepentingan wakaf.

Berikut merupakan bagan pelaksanaan wakaf dan tabel perbandingan antara beberapa jenis wakaf berdasar objeknya: ${ }^{16}$

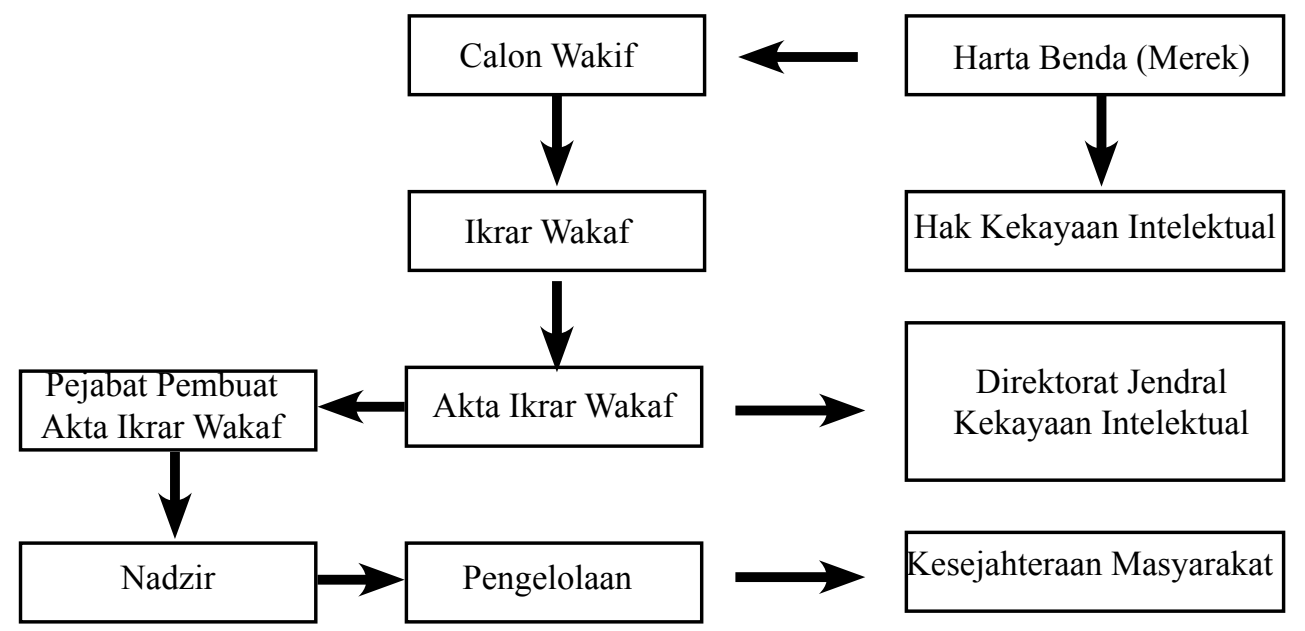

${ }^{16}$ Budi Agus Riswandi, Op.Cit., h. 136. 


\begin{tabular}{|c|c|c|c|}
\hline & \multicolumn{3}{|c|}{ PERBANDINGAN BEBERAPA JENIS WAKAF } \\
\hline & Wakaf Hak Atas Tanah & Wakaf Uang & Wakaf Merek \\
\hline Persamaan & \multicolumn{3}{|c|}{$\begin{array}{l}\text { - Adanya Wakif } \\
\text { - Adanya Nadzir } \\
\text { - Adanya Ikrar Wakaf } \\
\text { - Tujuan wakaf untuk kepentingan sosial } \\
\text { - Pengumuman harta benda wakaf dilakukan oleh kantor Departemen Agama dan } \\
\text { Badan Wakaf Indonesia }\end{array}$} \\
\hline Perbedaan & $\begin{array}{l}\text { - Objek wakaf berupa Hak } \\
\text { Atas Tanah } \\
\text { - Pernyataan kehendak } \\
\text { wakif dituangkan dalam } \\
\text { Akta ikrar Wakaf } \\
\text { - Kepemilikan dibuktikan } \\
\text { dengan alat bukti autentik } \\
\text { lazimnya (sertifikat hak } \\
\text { atas tanah) } \\
\text { - Pejabat Pembuat Akta } \\
\text { Ikrar Wakaf (PPAIW) } \\
\text { adalah Kepala KUA/ } \\
\text { Pejabat lain yang } \\
\text { menyelenggarakan } \\
\text { urusan wakaf } \\
\text { - Lembaga yang terkait } \\
\text { adalah Kantor Pertanahan } \\
\text { kabupaten/kota } \\
\text { - Objek wakaf hak atas } \\
\text { tanah ada yang berjangka } \\
\text { waktu (Hak Guna } \\
\text { Bangunan,dan Hak Guna } \\
\text { Usaha) dan ada yang } \\
\text { tidak berjangka waktu } \\
\text { (Hak milik atas tanah) }\end{array}$ & $\begin{array}{l}\text { - Objek wakaf berupa } \\
\text { uang } \\
\text { - Pernyataan kehendak } \\
\text { wakif dituangkan } \\
\text { dalam bentuk } \\
\text { sertifikat wakaf uang } \\
\text { - Tidak ada alat bukti } \\
\text { kepemilkan uang } \\
\text { - Pejabat Pembuat Akta } \\
\text { Ikrar Wakaf (PPAIW) } \\
\text { adalah Pejabat } \\
\text { Lembaga Keuangan } \\
\text { Syariah paling rendah } \\
\text { setingkat Kepala seksi } \\
\text { LKS yang ditunjuk } \\
\text { oleh Menteri } \\
\text { - Lembaga yang terkait } \\
\text { adalah Lembaga } \\
\text { Keuangan Syariah } \\
\text { - Objek wakaf uang } \\
\text { tidak berjangka waktu }\end{array}$ & $\begin{array}{l}\text { - Objek wakaf berupa } \\
\text { merek } \\
\text { - Pernyataan kehendak } \\
\text { wakif dituangkan } \\
\text { dalam Akta ikrar } \\
\text { Wakaf } \\
\text { - Kepemilikan } \\
\text { dibuktikan dengan } \\
\text { alat bukti autentik } \\
\text { lazimnya (sertifikat } \\
\text { merek) } \\
\text { - Pejabat Pembuat Akta } \\
\text { Ikrar Wakaf (PPAIW) } \\
\text { adalah Kepala KUA/ } \\
\text { Pejabat lain yang } \\
\text { ditunjuk Menteri } \\
\text { - Lembaga yang terkait } \\
\text { adalah Direktorat } \\
\text { Jendral Kekayaan } \\
\text { Intelektual } \\
\text { - Objek wakaf merek } \\
\text { berjangka waktu }\end{array}$ \\
\hline
\end{tabular}

\section{Jangka Waktu Wakaf Merek.}

Menurut Pasal 1 angka 1 UU Wakaf, dinyatakan bahwa wakaf adalah perbuatan hukum wakif untuk memisahkan dan/atau menyerahkan sebagian harta benda miliknya untuk dimanfaatkan selama-lamanya atau jangka waktu tertentu sesuai dengan kepentinganya guna keperluan ibadah dan/atau kesejahteraan umum menurut syariah.

Berdasarkan Undang-Undang No.20 Tahun 2016 tentang Merek dan Indikasi Geografis, dalam Pasal 35 ayat (1) dikatakan bahwa merek terdaftar mendapat perlindungan hukum untuk jangka waktu 10 (sepuluh) tahun sejak 
tanggal penerimaan. Selanjutnya dalam ayat (2) dikatakan bahwa jangka waktu perlindungan sebagaimana dimaksud pada ayat (1) dapat diperpanjang untuk jangka waktu yang sama.

Merek merupakan hak yang berjangka waktu. Hal ini membawa konsekuensi bahwa kepemilikan merek tidak bersifat selamanya, namun berjangka waktu. Berdasarkan definisi wakaf yang disebutkan dalam Pasal 1 angka 1 UU Wakaf, seolah-olah wakaf dapat dilaksanakan dalam jangka waktu tertentu dan selanjutnya dapat dicabut kembali. Namun yang sebenarnya terjadi tidak demikian, wakaf memang harus dilakukan selama-lamanya, yakni dalam hal wakif melapas harta bendanya yang telah diwakafkan. Jadi tidak boleh hukumnya wakif mencabut kembali ikrar wakaf atas benda benda yang telah diwakafkanya dengan alasan apapun, karena memang demikian konsep wakaf yang sebenarnya.

Jangka waktu di sini dimaksudkan untuk objek harta benda wakaf. UU Wakaf mengatur tentang objek harta benda wakaf yang secara umum dibagi menjadi wakaf hak atas tanah, wakaf uang, dan wakaf benda bergerak selain uang. Tentu dari ketiga macam objek wakaf benda tersebut tidak semuanya bersifat selamanya dalam hal kepemilikan, namun ada yang bersifat sementara, seperti hak guna bangunan, merek, paten, dan lain-lain. Jadi makna wakaf dapat berjangka waktu maksudnya adalah melekat pada objek benda wakafnya, bukan kegiatan inti wakafnya. Jangka waktu yang dimaksud tujuanya adalah untuk memberi peluang bagi wakif untuk mewakafkan harta benda yang berjangka waktu.

Jadi, berdasarkan uraian di atas wakaf merek harus dilakukan selamanya dalam pengertian wakif melapas hak atas mereknya. Sementara makna jangka waktu melekat pada perlindungan mereknya. Jika dalam UU Merek dikatakan perlindungan hak atas merek adalah 10 tahun dan dapat diperpanjang untuk jangka waktu yang sama, maka dalam hal wakif mewakafkan mereknya untuk pertama kali, nadzir sebagai pengelola harta benda wakaf dapat memanfaatkan merek yang telah diwakafkan tersebut untuk jangka waktu 10 tahun dan dapat diperpanjang. Namun apabila jangka waktu perlindungan merek tersebut habis dan tidak diperpanjang oleh nadzir, maka merek tersebut akan hilang, begitu juga hak-hak yang melekat didalamnya. 


\section{Kesimpulan}

Merek dalam wakaf termasuk dalam benda bergerak tidak berwujud. Merek termasuk dalam kategori benda karena memenuhi unsur-unsur dapat dikuasai dengan hak milik. Hal tersebut sesuai dengan definisi kebendaan yang diatur dalam Pasal 499 BW. Merek bisa dikuasai dengan hak milik, dibuktikan dengan adanya sertifikat merek. Hanya merek terdaftar saja yang dapat dialihkan dengan wakaf, karena syarat administrasi dari pengalihan merek salah satunya adalah alat bukti autentik kepemilkan hak berupa sertifkat.

Wakaf merek dilakukan dengan melampirkan alat bukti autentik berupa sertifkat kepemilikan hak yang dibuat oleh Ditjen HKI. Permohonan wakaf merek wajib dicatatkan kepada Ditjen HKI untuk dimuat dalam Daftar Umum HKI. Dalam permohonan tersebut juga harus menyertakan AIW yang diterbitkan oleh PPAIW. Setelah proses pencatatan selesai maka tahap selanjutnya adalah dilakukan pengumuman dalam Berita Resmi HKI Merek. Dengan diumumkanya pengalihan merek teresebut, maka sejak saat itu penerima manfaat dari merek tersebut beralih dari wakif kepada nadzir dan untuk selanjutnya manfaat dari merek tersebut digunakan untuk kepentingan umum.

\section{Daftar Bacaan}

\section{Buku}

Doi, Abdur Rahman, Inilah Syariah Islam, Pustaka Panji Mas, Jakarta, 1991.

Haq, Faishal, Hukum Perwakafan Di Indonesia, Rajawali Pers, Jakarta, 2017.

Muhammad, Abdulkadir, Kajian Hukum Ekonomi Hak Kekayaan Intelektual, Citra Aditya Bhakti, Bandung, 2001.

Riswandi, Budi, Agus, Wakaf Hak Kekayaan intelektual, Pusat HKI FH UII, Yogyakarta, 2016.

Sofwan, Sri Soedewi Masjchoen, Hukum Perdata:Hukum Benda, Liberty, Yogyakarta, 1981.

Spence, Micahael, Intellectual Property, Oxford University Press, London, 2007. 


\section{Perundang-undangan}

Kitab Undang-Undang Hukum Perdata.

Undang-Undang Nomor 41 Tahun 2004 tentang Wakaf(Lembaran Negara Republik Indonesia Tahun 2004 Nomor 159).

Undang-Undang Nomor 15 Tahun 2001 tentang Merek (Lembaran Negara RI Tahun 2001 Nomor 110).

Undang-Undang Nomor 20 Tahun 2016 tentang Merek dan Indokasi Geografis (Lembaran Negara RI Tahun 2016 Nomor 252).

Peraturan Pemerintah Nomor 42 Tahun 2006 tentang Pelaksanaan Undang- Undang Nomor 41 Tahun 2004 tentang Wakaf (Lembaran Negara Republik Indonesia Tahun 2006 Nomor 105).

Instruksi Presiden No.1 Tahun 1991 tentang Kompilasi Hukum Islam

\section{Jurnal}

Jened, Rahmi, Implikasi Persetujuan TRIPs Bagi Perlindungan Merek, Yuridika Fakultas Hukum Universitas Airlangga, Surabaya, 2000.

Sujatmiko, Agung, Perjanjian Lisensi Merek Terkenal, Mimbar Hukum Fakultas Hukum UGM, Vol. 22, 2010.

\section{Karya Ilmiah}

Rahmah, Mas, Sekuritas Hak Kekayaan Intelektual Untuk Penerbitan Sukuk, Disertasi, Program Doktor Ilmu Hukum, Fakultas Hukum Universitas Airlangga, 2012.

\section{Laman}

Kementrian Agama Republik Indonesia, Wakaf Fiqh, www.kemenag.go.id, Juli 2006, h.15, dikunjungi pada tanggal 1 April 2018. 